\title{
Weed Control and Peanut Tolerance with Ethalfluralin-Based Herbicide Systems
}

\author{
W. J. Grichar ${ }^{1}$ and P. A. Dotray ${ }^{2}$ \\ ${ }^{1}$ Texas AgriLife Research, 3507 Highway 59E, Beeville, TX 78102, USA \\ ${ }^{2}$ Texas Tech University, Texas AgriLife Research, and Texas AgriLife Extension Service, Lubbock, TX 79403, USA
}

Correspondence should be addressed to W. J. Grichar, w-grichar@tamu.edu

Received 23 November 2010; Revised 15 February 2011; Accepted 30 March 2011

Academic Editor: Kent Burkey

Copyright ( 2012 W. J. Grichar and P. A. Dotray. This is an open access article distributed under the Creative Commons Attribution License, which permits unrestricted use, distribution, and reproduction in any medium, provided the original work is properly cited.

\begin{abstract}
Field studies were conducted from 2007 through 2009 to determine weed efficacy and peanut (Arachis hypogaea L.) response to herbicide systems that included ethalfluralin applied preplant incorporated. Control of devil's claw (Proboscidea louisianica (Mill.) Thellung), yellow nutsedge (Cyperus esculentus L.), Palmer amaranth (Amaranthus palmeri S. Wats.), and puncturevine (Tribulus terrestris L.) was most consistent with ethalfluralin followed by either imazapic or imazethapyr applied postemergence. Peanut stunting was 19\% when paraquat alone was applied early-postemergence. Stunting increased to greater than $30 \%$ when ethalfluralin applied preplant incorporated was followed by $S$-metolachlor applied preemergence and paraquat applied earlypostemergence. Stunting $(7 \%)$ was also observed when ethalfluralin was followed by flumioxazin plus $S$-metolachlor applied preemergence with lactofen applied mid-postemergence. Ethalfluralin followed by paraquat applied early-postemergence reduced peanut yield when compared to the nontreated check. Ethalfluralin applied preplant incorporated followed by imazapic applied mid-postemergence provided the greatest yield $(6220 \mathrm{~kg} / \mathrm{ha})$. None of the herbicide treatments reduced peanut grade (sound mature kernels plus sound splits) when compared with the nontreated check.
\end{abstract}

\section{Introduction}

Peanut has several unique features that contribute to challenging weed management. Peanut cultivars grown in the United States require a fairly long growing season (140 to $160 \mathrm{~d}$ ), depending on cultivar and geographical region $[1,2]$. Consequently, soil-applied herbicides may not provide season-long control, and mid-to-late season weed pressure may occur. Peanut has a prostrate growth habit, a relatively shallow canopy, and is slow to shade interrows allowing weeds to be more competitive [2,3]. Additionally, peanut fruit develops underground on pegs originating from branches that grow along the soil surface. This prostrate growth habit and pattern of fruit development restricts cultivation to an early-season control option [2,4]. With conventional row spacing (91 to $102 \mathrm{~cm}$ ), complete ground cover may not be attained until 8 to $10 \mathrm{wk}$ after planting. In some areas of the U.S. peanut growing region, complete canopy closure may never occur.
Weeds compete with peanut for sunlight, moisture, and nutrients and may reduce harvesting efficiency. Weeds are particularly troublesome during digging and inverting procedures [5]. Weed biomass slows field-drying of peanut vines and pods and increases the likelihood of exposure to rainfall, which may increase harvesting losses $[2,5]$. The fibrous root system of annual grasses is extremely difficult to separate from peanut [6].

The dinitroaniline herbicides are registered for use in over forty crops [7]. These herbicides provide excellent control of annual grasses $[2,8,9]$ and are the only soil-applied herbicides registered for use in peanut that will provide full-season control of Texas panicum (Panicum texanum L.) $[2,10,11]$. Peanut tolerance to the dinitroaniline herbicides has been questioned previously [12-14]. Greenhouse studies showed that ethalfluralin inhibited seedling growth more than pendimethalin at equivalent rates applied preplant incorporated; however, injury by these herbicides following 
preemergence (PRE) applications were similar [15]. In runner peanuts, which are more prone to peg injury compared to Spanish peanut, proper herbicide incorporation was needed to prevent injury. Merkle [16] stated that sporadic injury to runner peanut from trifluralin was due to the failure to properly incorporate the herbicide. No differences were observed in a study examining peanut growth, yield, and grade effects with ethalfluralin, pendimethalin, or trifluralin in two different studies $[13,17]$. In Florida, ethalfluralin did not cause peanut injury at any rate or application timing [12]. Dinitroaniline injury on peanut includes a swollen hypocotyl, abnormal lateral root growth, and stunted plants $[15,16]$.

Metolachlor is commonly used in peanut for control of small-seeded broadleaf weeds, some annual grasses, and yellow nutsedge [18]. S-metolachlor is labeled in peanut for either preplant incorporated (PPI), post-plant incorporated, PRE, postemergence (POST), or at lay-by [19]. The Smetolachlor registered rate for the southwest is 1.1 to $1.4 \mathrm{~kg} / \mathrm{ha}$ [19]. However, many growers have reported peanut stunting when PPI or PRE applications of metolachlor have been followed by large amounts of rain [18]. Grichar and Colburn [18] reported that POST applications of metolachlor followed by ( $\mathrm{fb}$ ) irrigation within $24 \mathrm{~h}$ could be effective for yellow nutsedge control and reduce the chance of peanut injury from soil applications. Combinations of factors, such as herbicide rate, moisture conditions at planting, soil organic matter, and $\mathrm{pH}$ may affect peanut injury by chloroacetamide herbicides such as $S$-metolachlor [20-23]. Cardina and Swann [20] reported that metolachlor often delayed peanut emergence and reduced peanut growth when irrigation followed planting. However, yield loss was observed only when metolachlor was applied at three times the manufacturer's suggested use rate.

Several postemergence herbicides are used to control weed escapes. Imazethapyr and imazapic are imidazolinone herbicides registered for use in peanut. Imazethapyr may be applied PPI, PRE, ground cracking (GC), and POST for effective weed control [2]. Imazethapyr applied PPI or PRE controls many troublesome weeds such as coffee senna (Cassia occidentalis L.), common lambsquarters (Chenopodium album L.), morninglory species (Ipomoea spp.), pigweed species (Amaranthus spp.) including Palmer amaranth, prickly sida (Sida spinosa L.), purple (Cyperus rotundus L.), yellow nutsedge, spurred anoda [Anoda cristata (L.) Schlecht.], and wild poinsettia (Euphorbia heterophylla L.) [24-26].

Imazethapyr applied POST provided broad spectrum and most consistent control when applied within $10 \mathrm{~d}$ of weed emergence $[24,27]$. Imazethapyr and imazapic are the only POST herbicides to effectively control both yellow and purple nutsedge $[26,28]$. Control is most effective when imazethapyr is applied to the soil or to yellow nutsedge that is no more than $13 \mathrm{~cm}$ tall $[2,27,28]$.

Imazapic is similar to imazethapyr and controls all the weeds controlled by imazethapyr [27, 29]. In addition, imazapic provides control and suppression of Florida beggarweed [Desmodium tortuosum (S.W.) D.C.] and sicklepod [Senna obtusifolia (L.) Irwin and Barneby], which are not adequately controlled by imazethapyr [30]. Imazethapyr provides consistent control of many broadleaf and sedge species if applied within $10 \mathrm{~d}$ after emergence, but imazapic has a longer effectiveness period when applied POST [2, 28, 29, 31]. Imazapic also is effective for control of rhizome and seedling johnsongrass [Sorghum halepense (L.) Pers.], Texas panicum, large crabgrass [Digitaria sanguinalis (L.) Scop.], southern crabgrass [Digitaria ciliaris (Retz.) Koel.], and broadleaf signalgrass [Brachiaria platyphylla (Griseb.) Nash] [29].

Peanut tolerance to paraquat was first noted in the late 1970s [2]. Wehtje et al. [21] reported that paraquat controlled Texas panicum when applied sequentially, and Johnson III et al. [32] noted differences in cultivar tolerance. Paraquat is often tank-mixed with bentazon and can be applied up to $28 \mathrm{~d}$ after peanut emergence [2, 33]. Bentazon increases control of paraquat-tolerant species such as bristly starbur (Acanthospermum hispidum DC.), coffee senna, prickly sida, and smallflower morninglory [Jacquemontia tamnifolia (L.) Griseb.] [34] and reduces paraquatinduced injury to peanut [34]. Paraquat is a standard herbicide in southeastern U.S. peanut weed management [34, 35]. However, paraquat lacks residual activity and has a narrow window of application [2].

Lactofen was registered for POST application for peanut in 2005 for control of several annual broadleaf weeds including annual morningglories [36]. Peanut and soybean (Glycine $\max$ L.) tolerance to lactofen is based on metabolism, which often results in some leaf bronzing and spotting of leaves and plant growth is often temporarily reduced [37].

Flumioxazin is a soil-applied herbicide that received a federal label in the U.S. for use in peanut in 2001 [38]. In Georgia, flumioxazin applied PRE was shown to control morninglory spp., prickly sida, and Florida beggarweed [39] while in Texas pitted morninglory [Ipomoea lacunose L.] was controlled greater than 75\% with PRE applications of flumioxazin [17].

The herbicide 2,4-DB has provided inexpensive broadleaf weed control in peanut for many years [2, 8, 40]. Visual injury symptoms of 2,4-DB can be observed in the form of rolled or elongated foliage $[41,42]$.

Growers in the southwest consider ethalfluralin to be the premier dinitroaniline herbicide used in peanut production. The objectives of this research were to evaluate weed efficacy and/or peanut crop tolerance to soil-applied applications of ethalfluralin $\mathrm{fb}, \mathrm{PRE}$, and POST applications of commonly used peanut herbicides.

\section{Materials and Methods}

2.1. Field Studies. Studies were conducted in south Texas in a peanut grower's field near Pearsall from 2007 through 2009 and in the High Plains area near Lubbock in 2008 and 2009 under noncropland conditions to determine weed control with ethalfluralin applied PPI followed by PRE and/or early postemergence (EPOST) or mid-postemergence (MPOST) treatments of several commonly used peanut herbicides. Peanut tolerance was also evaluated at the south Texas location. The south Texas study was located in the same 
general area and with the same producer but in different fields near Pearsall on a Duval loamy fine sand (fine-loamy, mixed, hyperthermic aridic Haplustalfs) with less than $1 \%$ organic matter and pH 6.9 to 7.2. The High Plains location was at the Texas AgriLife Research and Extension Center near Lubbock on an Acuff loam (fine-loamy, mixed, thermic aridic Paleustoll) with $0.8 \%$ organic matter and $\mathrm{pH} 7.8$.

The peanut cultivar Tamrun OL02 [43] was planted at the south Texas location using a seeding rate of 90 to $110 \mathrm{~kg} / \mathrm{ha}$ in all years. Each plot consisted of two rows spaced $97 \mathrm{~cm}$ apart and $7.6 \mathrm{~m}$ long, while in the High Plains location, plots were $4.1 \mathrm{~m}$ wide by $9.1 \mathrm{~m}$ long. At the south Texas location, sprinkler irrigation was applied on a 2- to 3-wk schedule throughout the growing season as deemed necessary by the grower. All field plots were naturally infested with moderate to high populations of yellow nutsedge ( 6 to 8 plants $/ \mathrm{m}^{2}$ ), Palmer amaranth (in south Texas in 2007, 4 to 6 plants $/ \mathrm{m}^{2}$, in 2008,1 to 2 plants $/ \mathrm{m}^{2}, 12$ to 15 plants $/ \mathrm{m}^{2}$ in the High Plains), devil's claw ( 1 to 4 plants $/ \mathrm{m}^{2}$ ), and puncturevine (1 to 2 plants $/ \mathrm{m}^{2}$ ).

The experiment was conducted as a randomized complete block design with three replications. An nontreated check was included in each experiment. Herbicide treatments included ethalfluralin alone at $0.84 \mathrm{~kg}$ ai $/$ ha applied PPI, ethalfluralin fb imazethapyr at $0.07 \mathrm{~kg}$ ai $/$ ha applied MPOST, ethalfluralin fb imazapic at $0.07 \mathrm{~kg}$ ai $/$ ha applied MPOST, ethalfluralin $\mathrm{fb}$ imazapic at $0.035 \mathrm{~kg}$ ai $/$ ha applied EPOST fb imazapic at $0.035 \mathrm{~kg} / \mathrm{ha}$ applied MPOST, ethalfluralin $\mathrm{fb}$ bentazon at $1.12 \mathrm{~kg}$ ai/ha applied MPOST, ethalfluralin $\mathrm{fb}$ acifluorfen at $0.42 \mathrm{~kg}$ ai $/$ ha applied MPOST, ethalfluralin fb lactofen at $0.22 \mathrm{~kg}$ ai/ha applied MPOST, ethalfluralin $\mathrm{fb} 2,4-\mathrm{DB}$ at $0.44 \mathrm{~kg}$ ai $/$ ha applied MPOST, ethalfluralin $\mathrm{fb}$ paraquat at $0.28 \mathrm{~kg}$ ai $/$ ha applied EPOST, ethalfluralin $\mathrm{fb}$ $S$-metolachlor at $1.1 \mathrm{~kg}$ ai $/$ ha applied PRE fb paraquat at $0.28 \mathrm{~kg} / \mathrm{ha}$ applied EPOST, ethalfluralin fb flumioxazin at $0.11 \mathrm{~kg}$ ai $/$ ha applied PRE, ethalfluralin fb flumioxazin at $0.11 \mathrm{~kg} / \mathrm{ha}$ plus $S$-metolachlor at $1.1 \mathrm{~kg} / \mathrm{ha}$ applied PRE, ethalfluralin $\mathrm{fb} S$-metolachlor at $1.1 \mathrm{~kg} / \mathrm{ha}$ applied PRE $\mathrm{fb}$ lactofen at $0.22 \mathrm{~kg} /$ ha applied MPOST, and ethalfluralin $\mathrm{fb}$ flumioxazin at $0.11 \mathrm{~kg} /$ ha plus $S$-metolachlor at $1.1 \mathrm{~kg} / \mathrm{ha}$ applied PRE fb lactofen at $0.22 \mathrm{~kg} /$ ha applied MPOST. Where peanut were planted, PRE herbicide applications were made immediately after planting in 2007 and 2009 and 3d after planting in 2008. Early-postemergence applications were made approximately 3 to $4 \mathrm{wk}$ after planting when Palmer amaranth was approximately 10 to $15 \mathrm{~cm}$ tall, while MPOST applications were made approximately 6 to $7 \mathrm{wk}$ after planting when Palmer amaranth was 20 to $30 \mathrm{~cm}$ tall. All POST herbicide applications included either a crop oil concentrate (Agri-Dex, a blend of $83 \%$ paraffin-based petroleum oil and 17\% surfactant; Helena Chemical Company, Suite 500, 6075 Poplar Avenue, Memphis, TN 38137) at $2.3 \mathrm{~L} /$ ha or a nonionic surfactant (X-77, 90\% non-ionic surfactant; Loveland Industries, P.O. Box 1289, Greeley, CO 80632) at 0.25\% v/v.

At the south Texas location ethalfluralin was applied with a tractor-mounted sprayer equipped with Teejet 11002 DG flat fan spray tips (Spraying Systems Company, P.O. Box 7900, North Avenue, Wheaton, IL 60188). A rolling cultivator with mixing wheels was used to incorporate ethalfluralin immediately after application. The mixing wheels consisted of four to six spider gangs approximately 10 to $13 \mathrm{~cm}$ long mounted on a gang tube which were set to incorporate the herbicide no greater than $2 \mathrm{~cm}$. These gangs help to lift and mix the soil. Gang angle was set to maintain the shape of the raised beds. All PRE and POST herbicides were applied with a $\mathrm{CO}_{2}$ pressurized backpack sprayer equipped with Teejet 11002 DG which delivered a spray volume of $190 \mathrm{~L} \mathrm{ha}^{-1}$ at $180 \mathrm{kPa}$. At the High Plains location, PPI and PRE herbicides were applied with a tractor-mounted sprayer using Teejet 110015 TT flat fan nozzles. In both years, both PPI and PRE herbicides were sprayed and incorporated $(2$ to $3 \mathrm{~cm}$ ) with a rolling cultivator. All POST herbicides were applied with a $\mathrm{CO}_{2}$ pressurized backpack sprayer using Teejet 110015 TT flat fan nozzles calibrated to deliver a spray volume of $95 \mathrm{~L} \mathrm{ha}^{-1}$ at $207 \mathrm{kPa}$.

Weed control and peanut injury (expressed as stunting) were estimated visually on a scale of 0 to 100 with 0 indicating no weed control or peanut stunting to 100 indicating complete weed control or peanut stunting (plant death), relative to the nontreated check [44]. At the High Plains location, weed-control ratings were taken approximately 90 days after ethalfluralin was applied while at the south Texas location weed control and peanut stunting evaluations recorded prior to digging of peanut are presented. Peanut yields were obtained by digging each plot separately, air-drying in the field for 4 to $7 \mathrm{~d}$, and harvesting peanut pods from each plot with a combine. Weights were recorded after soil and trash were removed from plot samples. Grade samples were determined using screens specified in USDA grading procedures [45].

2.2. Statistical Analysis. Peanut injury data were transformed to the arcsine square root prior to analysis of variance but are expressed in their original form for clarity because the transformation did not alter interpretation. Visual estimates of peanut injury, yield, and grade were subjected to analysis of variance to test effects of POST herbicide and application timing. Means were compared with the appropriate Fisher's Protected LSD test at the 5\% probability level. The nontreated check was not included in peanut stunting analysis but was included in peanut yield and grade analysis.

\section{Results and Discussion}

At the High Plains location, under non-cropland conditions, devil's-claw and Palmer amaranth were present both years while puncturevine was present only in 2009. Devil's-claw and Palmer amaranth data were not combined over years due to a treatment by year interaction. At the south Texas location, yellow nutsedge was present in 2008 and 2009 while Palmer amaranth was present in 2007 and 2008. Yellow nutsedge data were combined over years since there was not a treatment by year interaction; however, Palmer amaranth data are presented separately by years due to a treatment by year interaction. Peanut stunt, yield, and grade data were collected in 2008 and 2009 and combined over years due to a lack of treatment by year interaction. 
3.1. Devil's-Claw Control. In 2008, ethalfluralin alone controlled devil's-claw 20\% while herbicide systems which included either imazethapyr or imazapic provided at least $90 \%$ control of this species (Table 1). No other herbicide systems with the exception of ethalfluralin $\mathrm{fb}$ bentazon or 2,4-DB controlled devil's-claw better than 75\%. In 2009, herbicide systems which included either imazethapyr, 2,4$\mathrm{DB}$, paraquat alone, or flumioxazin alone failed to control devil's-claw. Herbicide systems which included imazapic, bentazon, lactofen, $S$-metolachlor fb paraquat, or lactofen controlled devil's-claw at least 90\%. Differences in control may be partially explained by differences in weather conditions between the two years. In 2008, extremely dry conditions existed from herbicide application through the first 6- to 8 -wk period with only approximately $3 \mathrm{~mm}$ of rainfall. In comparison, rainfall in 2009 for the same time period was approximately $32 \mathrm{~mm}$. Also, temperatures were much warmer in 2009 than 2008 during this time period (data not shown). In earlier work, Grichar et al. [46] reported that ethalfluralin alone did not control devil's-claw; however, ethalfluralin $\mathrm{fb}$ imazapic applied POST provided 100\% control. In commercial fields, imazapic has provided excellent devil's-claw control (author's personal observations).

3.2. Palmer Amaranth Control. At the High Plains location in 2008, ethalfluralin fb imazapic, ethalfluralin fb $S$ metolachlor applied PRE fb paraquat applied EPOST, and ethalfluralin fb flumioxazin plus $S$-metolachlor with or without lactofen applied MPOST controlled Palmer amaranth at least $80 \%$ (Table 1). Ethalfluralin fb either bentazon, acifluorfen, or paraquat failed to control Palmer amaranth $(\leq 60 \%)$. In 2009, all herbicide systems controlled Palmer amaranth at least $90 \%$ with the exception of ethalfluralin $\mathrm{fb}$ bentazon which controlled this weed $87 \%$. At the south Texas location in 2007, all herbicide systems with the exception of ethalfluralin alone, ethalfluralin $\mathrm{fb}$ imazethapyr or bentazon control Palmer amaranth at least $88 \%$, while in 2008, all herbicide systems controlled Palmer amaranth at least $91 \%$ (Table 2). Increased herbicide efficacy with herbicide systems in 2008 was due to the lack of high Palmer amaranth populations that were observed in 2007.

Grichar and Nester [47] reported that imazapic controlled Palmer amaranth at least $80 \%$ regardless of application timing while acifluorfen, bentazon, or 2,4-DB failed to control Palmer amaranth $(<70 \%)$ regardless of application timing. In 2005, acifluorfen, imazapic, imazethapyr, 2,4DB, and lactofen controlled Palmer amaranth at least $96 \%$ regardless of application timing. Bentazon failed to control Palmer amaranth $(<50 \%)$. In earlier work, imazapic at 0.04 to $0.07 \mathrm{~kg} /$ ha controlled Palmer amaranth at least $95 \%$ when applied EPOST while imazethapyr provided at least $90 \%$ control in 2 of the 3 yr [47]. Mayo et al. [48] concluded that Palmer amaranth control generally decreased as application timing was delayed for acifluorfen, imazethapyr, or lactofen. Acifluorfen at 0.42 and $0.56 \mathrm{~kg} / \mathrm{ha}$ controlled Palmer amaranth at least $94 \%$ in 2 of 3 test years, while lactofen controlled Palmer amaranth 99\% in two years and $80 \%$ the other year [47]. Bentazon usually does not control pigweed species [8].
3.3. Puncturevine Control. Herbicide systems which included bentazon, $S$-metolachlor fb paraquat, and flumioxazin plus $S$-metolachlor provided $100 \%$ puncturevine control, while systems which included imazapic controlled this weed at least 92\% (Table 1). Ethalfluralin alone, ethalfluralin $\mathrm{fb}$ acifluorfen, or paraquat failed to control puncturevine.

3.4. Yellow Nutsedge Control. Herbicide systems that included imazethapyr or imazapic controlled yellow nutsedge at least $83 \%$, while herbicide systems which included $S$ metolachlor, controlled yellow nutsedge no better than $75 \%$ (Table 2). Lack of yellow nutsedge control with flumioxazin in other studies $[18,39]$ suggest the need for a chloroacetamide herbicide when this weed is present. Askew et al. [49] reported that metolachlor PRE complemented a flumioxazin-based program by controlling goosegrass [Eleusine indica (L.) Gaertn.] and yellow nutsedge. Scott et al. [50] reported that metolachlor alone applied PPI or metolachlor followed by flumioxazin PRE controlled at least $86 \%$ yellow nutsedge. However, the addition of $S$-metolachlor to flumioxazin systems provided inconsistent yellow nutsedge control in this study. Bentazon will suppress yellow nutsedge growth, but control may be incomplete due to the lack of sufficient translocation in the plant [27]. Imazethapyr applied PRE controls yellow nutsedge, but control can be inconsistent [25, 26]. Grichar and Nester [47] found that imazapic at 50 and $70 \mathrm{~g} / \mathrm{ha}$ controlled yellow nutsedge $88 \%$ in the early season but was inconsistent later in the season. Wilcut et al. [27] reported that imazapic controlled yellow nutsedge greater than $90 \%$ at rates as low as $40 \mathrm{~g} / \mathrm{ha}$. Grichar and Sestak [51] also reported that imazapic provided at least $80 \%$ control of yellow nutsedge.

3.5. Peanut Stunt. Herbicide systems that included paraquat resulted in severe peanut stunting, while the herbicide system which included flumioxazin plus $S$-metolachlor fb lactofen, caused moderate peanut stunting (Table 2). No other herbicide system resulted in significant stunting, although paraquat is registered for use on peanut within $28 \mathrm{~d}$ after emergence, Johnson III et al. [32] stated that paraquat use later than $28 \mathrm{~d}$ after emergence is discouraged due to the potential for crop injury with less time for plant recovery. Although paraquat was applied within the time frame regarded as safe to the crop, excessive stunting was still observed. Peanut cultivar response to paraquat was thought to be the issue; however, Wehtje et al. [52] reported that foliar absorption and translocation of paraquat did not vary between peanut cultivars, and they attributed yield difference to the difference in yield potential between cultivars.

Peanut stunting with metolachlor has been noted in other studies [20, 21, 38, 53]. In Georgia, early-season peanut growth suppression was related to metolachlor rate [20]. Later-developing pods were not affected by metolachlor, and over the long period of pod development, the effect of metolachlor on early-developing pods was masked by the greater contribution of later developing pods to the final yield. Grichar et al. [38] reported that flumioxazin plus metolachlor combinations, under cool, wet conditions, 
TABle 1: Weed control in the Texas High Plains with herbicide systems which include ethalfluralin. ${ }^{\mathrm{a}}$

\begin{tabular}{|c|c|c|c|c|c|c|}
\hline \multirow{3}{*}{ Treatments $^{\mathrm{b}, \mathrm{c}}$} & \multirow{3}{*}{ Application timing } & \multicolumn{2}{|c|}{ Devil's claw } & \multicolumn{2}{|c|}{ Palmer amaranth } & \multirow{3}{*}{$\begin{array}{c}\text { Puncture vine } \\
2009\end{array}$} \\
\hline & & 2008 & 2009 & 2008 & 2009 & \\
\hline & & \multicolumn{4}{|c|}{$\%$} & \\
\hline Nontreated & - & 0 & 0 & 0 & 0 & 0 \\
\hline Ethalfluralin & PPI & 20 & 0 & 72 & 90 & 62 \\
\hline Ethalfluralin $\mathrm{fb}$ imazethapyr & PPI fb MPOST & 90 & 50 & 73 & 94 & 83 \\
\hline Ethalfluralin fb imazapic & PPI fb MPOST & 100 & 93 & 80 & 96 & 97 \\
\hline $\begin{array}{l}\text { Ethalfluralin } \mathrm{fb} \\
\text { imazapic/imazapic }\end{array}$ & $\begin{array}{c}\text { PPI fb } \\
\text { EPOST/MPOST }\end{array}$ & 98 & 98 & 85 & 97 & 92 \\
\hline Ethalfluralin fb bentazon & PPI fb MPOST & 82 & 95 & 55 & 87 & 100 \\
\hline Ethalfluralin fb acifluorfen & PPI fb MPOST & 10 & 88 & 60 & 96 & 52 \\
\hline Ethalfluralin fb lactofen & PPI fb MPOST & 47 & 98 & 75 & 98 & 89 \\
\hline Ethalfluralin $\mathrm{fb} 2,4-\mathrm{DB}$ & PPI fb MPOST & 77 & 45 & 74 & 95 & 89 \\
\hline Ethalfluralin $\mathrm{fb}$ paraquat & PPI fb EPOST & 7 & 33 & 55 & 96 & 39 \\
\hline $\begin{array}{l}\text { Ethalfluralin/S-metolachlor fb } \\
\text { paraquat }\end{array}$ & PPI/PRE fb EPOST & 2 & 90 & 87 & 99 & 100 \\
\hline Ethalfluralin/flumioxazin & PPI/PRE & 15 & 38 & 76 & 99 & 92 \\
\hline $\begin{array}{l}\text { Ethalfluralin/flumioxazin }+ \\
S \text {-metolachlor }\end{array}$ & PPI/PRE & 15 & 68 & 86 & 100 & 100 \\
\hline $\begin{array}{l}\text { Ethalfluralin/S-metolachlor fb } \\
\text { lactofen }\end{array}$ & PPI/PRE fb MPOST & 50 & 100 & 78 & 99 & 95 \\
\hline $\begin{array}{l}\text { Ethalfluralin/flumioxazin }+ \\
S \text {-metolachlor fb lactofen }\end{array}$ & PPI/PRE fb MPOST & 63 & 100 & 88 & 100 & 89 \\
\hline LSD (0.05) & & 11 & 20 & 26 & 3 & 40 \\
\hline
\end{tabular}

abbreviations: fb: followed by; PPI: preplant incorporated; PRE: preemergence; EPOST: early postmemergence; MPOST: mid postemergence.

${ }^{b}$ Herbicide rates: ethalfluralin, $0.84 \mathrm{~kg} / \mathrm{ha}$; imazethapyr, $0.07 \mathrm{~kg} / \mathrm{ha}$; imazapic, $0.07 \mathrm{~kg} / \mathrm{ha}$ or the split rates of $0.035 \mathrm{~kg} / \mathrm{ha}$; bentazon, $1.12 \mathrm{~kg} / \mathrm{ha}$; acifluorfen, $0.42 \mathrm{~kg} / \mathrm{ha}$; lactofen, $0.22 \mathrm{~kg} / \mathrm{ha}$; 2,4-DB, $0.44 \mathrm{~kg} / \mathrm{ha} ;$ paraquat, $0.28 \mathrm{~kg} / \mathrm{ha} ; S$-metolachlor, $1.1 \mathrm{~kg} / \mathrm{ha}$; flumioxazin, $0.11 \mathrm{~kg} / \mathrm{ha}$.

${ }^{\mathrm{c}}$ POST treatments of bentazon, acifluorfen, lactofen, 2,4-DB included Agridex at 1\% v/v while POST treatments of imazapic, imazethapyr, or paraquat included Induce at $1 \% \mathrm{v} / \mathrm{v}$. MPOST treatment approximately $3 \mathrm{wk}$ after EPOST treatments.

${ }^{\mathrm{d}}$ Split application of imazapic. Second application followed the initial application by $6 \mathrm{wk}$ in 2008 and $2 \mathrm{wk}$ in 2009.

resulted in peanut stunting which was evident throughout the growing season. They attributed this to increased uptake of flumioxazin and metolachlor with the heavy rainfall and the slowed metabolism of these herbicides as a result of cool temperatures [38].

3.6. Peanut Yield and Grade. High weed densities in plots with poor control can result in the tight fibrous root system of the weed becoming intertwined with the peanut plant and digging equipment during the digging opearation. As a result, many peanut pods can be stripped from the peanut plant during digging. Peanut pods that become detached from the plant remain unharvested in or on the soil [8].

Plots treated with ethalfluralin fb imazapic at $0.07 \mathrm{~kg} / \mathrm{ha}$ produced the highest peanut yield, while herbicide systems which included acifluorfen, 2,4-DB, paraquat, or flumioxazin alone produced the least yield (Table 2). Other studies have not reported any yield reductions with the use of paraquat $[32,52,54]$. Peanut yields do not always reflect the levels of nutsedge control, especially if annual grasses and broadleaf weeds are controlled $[29,55]$. Also, Patterson et al. [56] and Johnson III and Mullinix [57] reported that yellow nutsedge was not as competitive with many crops, such as cotton (Gossypium hirsutum L.), as well as many annual weeds. However, yellow nutsedge needs to be controlled, since nutsedge tubers can contaminate peanut and confectionary products, increasing food industry liability [58].

Peanut grade (sound mature kernels plus sound splits) was not reduced from the nontreated check with any herbicide systems (Table 2). Carley et al. [54] reported that paraquat reduced the percentage of extra large kernels (ELK) from $45 \%$ (nontreated peanut) to $41 \%$ in one year but did not affect percentage ELK in another year on Virginia market type cultivars. Previous research suggests that paraquat may affect peanut grade (especially Virginia market types) by increasing the proportion of other kernels [59], which may indicate that the herbicide affected grade by delaying maturity [54].

\section{Conclusions}

Results from this research demonstrate that ethalfluralin $\mathrm{fb}$ POST applications of imazethapyr and imazapic were the most effective herbicide systems for control of all the weeds that may be present in a peanut field in Texas. Although some growers in the southwestern United States peanut production region are of the opinion that a total POST program using imazapic or imazethapyr is sufficient, the use of a soil-applied 
TABLE 2: Weed control, peanut yield, and grade with herbicide systems in south Texas which include ethalfluralin.,

\begin{tabular}{|c|c|c|c|c|c|c|c|}
\hline \multirow{3}{*}{ Treatments ${ }^{c}$} & \multirow{3}{*}{ Application timing } & \multirow{3}{*}{ Yellow nutsedge } & \multicolumn{2}{|c|}{ P. amaranth } & \multicolumn{3}{|c|}{ Peanut } \\
\hline & & & 2007 & 2008 & Stunt & Yield & Grade $^{\mathrm{d}}$ \\
\hline & & & $\%$ & & & $\mathrm{Kg} / \mathrm{ha}$ & $\%$ \\
\hline Nontreated & - & 0 & 0 & 0 & 0 & 5100 & 73.2 \\
\hline Ethalfluralin & PPI & 0 & 32 & 97 & 0 & 5670 & 73.5 \\
\hline Ethalfluralin fb imazethapyr & PPI fb MPOST & 93 & 67 & 100 & 1 & 5720 & 72.4 \\
\hline Ethalfluralin fb imazapic & PPI fb MPOST & 88 & 100 & 100 & 0 & 6220 & 73.0 \\
\hline $\begin{array}{l}\text { Ethalfluralin fb } \\
\text { imazapic/imazapic }\end{array}$ & $\begin{array}{c}\text { PPI fb } \\
\text { EPOST/MPOST }\end{array}$ & 83 & 100 & 93 & 2 & 5590 & 73.0 \\
\hline Ethalfluralin $\mathrm{fb}$ bentazon & PPI fb MPOST & 56 & 76 & 100 & 0 & 5500 & 73.1 \\
\hline Ethalfluralin fb acifluorfen & PPI fb MPOST & 0 & 98 & 91 & 0 & 4850 & 73.1 \\
\hline Ethalfluralin fb lactofen & PPI fb MPOST & 0 & 96 & 100 & 0 & 5650 & 73.6 \\
\hline Ethalfluralin $\mathrm{fb} 2,4-\mathrm{DB}$ & PPI fb MPOST & 0 & 93 & 100 & 4 & 4150 & 72.4 \\
\hline Ethalfluralin $\mathrm{fb}$ paraquat & PPI fb EPOST & 23 & 92 & 94 & 19 & 3530 & 71.7 \\
\hline $\begin{array}{l}\text { Ethalfluralin/S-metolachlor fb } \\
\text { paraquat }\end{array}$ & PPI/PRE fb EPOST & 75 & 100 & 100 & 33 & 4180 & 72.2 \\
\hline Ethalfluralin/flumioxazin & $\mathrm{PPI} / \mathrm{PRE}$ & 0 & 88 & 97 & 2 & 5090 & 74.0 \\
\hline $\begin{array}{l}\text { Ethalfluralin/flumioxazin }+ \\
\text { S-metolachlor }\end{array}$ & PPI/PRE & 37 & 99 & 100 & 0 & 5240 & 72.5 \\
\hline $\begin{array}{l}\text { Ethalfluralin/S-metolachlor } \mathrm{fb} \\
\text { lactofen }\end{array}$ & PPI/PRE fb MPOST & 72 & 100 & 100 & 5 & 5680 & 71.8 \\
\hline $\begin{array}{l}\text { Ethalfluralin/flumioxazin }+ \\
S \text {-metolachlor fb lactofen }\end{array}$ & PPI/PRE fb MPOST & 43 & 92 & 100 & 7 & 5350 & 73.6 \\
\hline $\operatorname{LSD}(0.05)$ & & 38 & 38 & 9 & 6 & 1140 & 2.0 \\
\hline
\end{tabular}

${ }^{a}$ Yellow nutsedge present in 2008 and 2009. Peanut yield and grade obtained in 2008 and 2009. Data combined over years.

b Abbreviations: fb: followed by; PPI: preplant incorporated; PRE: preemergence, EPOST: early postemergence, MPOST: mid-postemergence.

${ }^{\mathrm{c}}$ Herbicide rates: ethalfluralin, $0.84 \mathrm{~kg} / \mathrm{ha}$; imazethapyr, $0.07 \mathrm{~kg} / \mathrm{ha}$; imazapic, $0.07 \mathrm{~kg} / \mathrm{ha}$ or the split rates of $0.035 \mathrm{~kg} / \mathrm{ha}$; bentazon, $1.12 \mathrm{~kg} / \mathrm{ha}$; acifluorfen, $0.42 \mathrm{~kg} / \mathrm{ha}$; lactofen, $0.22 \mathrm{~kg} / \mathrm{ha} ; 2,4-\mathrm{DB}, 0.44 \mathrm{~kg} / \mathrm{ha}$; paraquat, $0.28 \mathrm{~kg} / \mathrm{ha} ; S$-metolachlor, $1.1 \mathrm{~kg} / \mathrm{ha}$; flumioxazin, $0.11 \mathrm{~kg} / \mathrm{ha}$. EPOST treatments applied 3 to 4 wk after planting followed by MPOST treatment approximately 3 wk later. All POST treatments included Agridex at $0.6 \% \mathrm{v} / \mathrm{v}$.

${ }^{\mathrm{d}}$ Grade, sound mature kernels (SMK) + sound splits (SS).

eSplit application of imazapic. Initial application approximately 3 to $4 \mathrm{wk}$ after planting followed by second application $3 \mathrm{wk}$ later.

herbicide is important in order to maintain season-long weed control and increase net returns $[13,18,46]$. Care must be taken to apply paraquat within the time frame regarded as safe to the crop since severe peanut stunting and yield reductions are possible [2].

Monoculture production systems and the repeated use of the same or similar herbicides have led to herbicide resistance in weeds [60-62]. Amaranthus species are very sensitive to ALS-inhibiting herbicides and possess characteristics, such as high genetic variability, prolific seed production, and efficient pollen and seed distribution, that predispose them to have herbicide resistant biotypes [63]. The use of soilapplied and POST herbicides with alternative sites of action is necessary to reduce the rate of development of herbicideresistant weed populations [64].

\section{References}

[1] R. J. Henning, A. H. Allison, and L. D. Tripp, "Cultural practices," in Peanut Science and Technology, H. E. Pattee and C. T. Young, Eds., pp. 123-138, American Peanut Research Education Society, Yoakum, Tex, USA, 1982.

[2] J. W. Wilcut, A. C. York, W. J. Grichar, and G. R. Wehtje, "The biology and management of weeds in peanut (Arachis hypogaea)," in Advances in Peanut Science, H. E. Pattee and H. T. Stalker, Eds., pp. 207-244, American Peanut Research Education Society, Stillwater, Okla, USA, 1995.

[3] R. H. Walker, L. W. Wells, and J. A. McGuire, "Bristly starbur (Acanthospermum hispidum) interference in peanuts (Arachis hypogaea)," Weed Science, vol. 37, pp. 196-200, 1989.

[4] B. J. Brecke and D. L. Colvin, "Weed management in peanuts," in CRC Handbook of Pest Management in Agriculture, D. Pimentel, Ed., vol. 3, pp. 239-251, CRC Press, Boca Raton, Fla, USA, 2nd edition, 1991.

[5] J. H. Young, N. K. Person, J. O. Donald, and W. H. Mayfield, "Harvesting, curing, and energy utilization," in Peanut Science and Technology, H. E. Pattee and C. T. Young, Eds., pp. 458487, American Peanut Research Education Society, Yoakum, Tex, USA, 1982.

[6] J. W. Wilcut, A. C. York, and G. R. Wehtje, "The control and interaction of weeds in peanut (Arachis hypogaea)," Review of Weed Science, vol. 6, pp. 177-205, 1994.

[7] Anonymous, Crop Protection Reference, Chemical \& Pharmaceutical Press, New York, NY, USA, 26th edition, 2010.

[8] G. A. Buchanan, D. S. Murray, and E. W. Hauser, "Weeds and their control in Peanuts," in Peanut Science and Technology, H. E. Pattee and C. T. Young, Eds., pp. 209-249, American Peanut Research Education Society, Yoakum, Tex, USA, 1982. 
[9] R. W. Chamblee, L. Thompson Jr., and T. M. Bunn, "Management of broadleaf signalgrass (Brachiaria platyphylla) in peanuts (Arachis hypogaea)," Weed Science, vol. 30, pp. 40-44, 1982.

[10] J. W. Wilcut, G. R. Wehtje, and R. H. Walker, "Economics of weed control in peanuts (Arachis hypogaea) with herbicides and cultivations," Weed Science, vol. 35, pp. 711-715, 1987.

[11] J. W. Wilcut, G. R. Wehtje, and M. G. Patterson, "Economic assessment of weed control systems for peanuts (Arachis hypogaea)," Weed Science, vol. 35, pp. 433-437, 1987.

[12] B. J. Brecke and W. L. Currey, "Weed control in peanuts with ethalfluralin," Peanut Science, vol. 7, pp. 124-127, 1980.

[13] P. A. Dotray, J. W. Keeling, W. J. Grichar, E. P. Prostko, and R. G. Lemon, "Peanut response to ethalfluralin, pendimethalin, and trifluralin preplant incorporated," Peanut Science, vol. 30, pp. 34-37, 2004.

[14] E. P. Prostko, W. C. Johnson III, and B. G. Mullinix Jr., "Annual grass control with preplant incorporaed and preemeergence applications of ethalfluralin and pendimethalin in peanut (Arachis hypogaea)," Weed Technology, vol. 15, pp. 36-41, 1999.

[15] W. C. Johnson III and B. G. Mullinix Jr., "Peanut seedling response to dinitroaniline herbicides applied preplant incorporated and preemergence," Peanut Science, vol. 26, pp. 28-32, 1999.

[16] M. G. Merkle, "Weed control," in Peanut Production in Texas, pp. 50-52, Texas Agricultural Experiment Station, College Station, Tex, USA, 1975.

[17] W. J. Grichar and A. E. Colburn, "Effect of dinitroaniline herbicides upon yield and grade of five runner cultivars," Peanut Science, vol. 20, pp. 126-128, 1993.

[18] W. J. Grichar and A. E. Colburn, "Flumioxazin for weed control in Texas peanuts (Arachis hypogaea L.)," Peanut Science, vol. 23, pp. 30-36, 1996.

[19] Anonymous, Dual Magnum label SCP 816A-L1N 0403, Syngenta Crop Protection, Greensboro, NC, USA, 2004.

[20] J. Cardina and C. W. Swann, "Metolachlor effects on peanut growth and development," Peanut Science, vol. 15, pp. 57-60, 1988.

[21] G. Wehtje, J. W. Wilcut, T. V. Hicks, and J. McGuire, "Relative tolerance of peanuts to alachlor and metolachlor," Peanut Science, vol. 15, pp. 53-56, 1988.

[22] B. T. Osborne, D. R. Shaw, and R. L. Ratliff, "Response of selected soybean (Glycine max) cultivars to dimethenamid and metolachlor in hydroponic conditions," Weed Technology, vol. 9, no. 1, pp. 178-181, 1995.

[23] T. C. Mueller, D. R. Shaw, and W. W. Witt, "Relative dissipation of acetochlor, alachlor, metolachlor, and SAN 582 from three surface soils," Weed Technology, vol. 13, no. 2, pp. 341-346, 1999.

[24] J. W. Wilcut, F. R. Walls Jr., and D. N. Norton, "Imazethapyr for broadleaf weed control in peanuts (Arachis hypogaea)," Peanut Science, vol. 18, pp. 26-30, 1991.

[25] J. W. Wilcut, F. R. Walls Jr., and D. N. Norton, "Weed control, yield, and net returns using imazethapyr in peanuts (Arachis hypogaea)," Weed Science, vol. 39, pp. 238-242, 1991.

[26] W. J. Grichar, P. R. Nester, and A. E. Colburn, "Nutsedge (Cyperus spp.) control in peanuts (Arachis hypogaea) with imazethapyr," Weed Technology, vol. 6, pp. 396-400, 1992.

[27] J. W. Wilcut, J. S. Richburg III, G. Wiley, F. R. Walls Jr., S. R. Jones, and M. J. Iverson, "Imidazolinone herbicide systems for peanut (Arachis hypogaea L.)," Peanut Science, vol. 21, pp. 2328, 1994.
[28] J. S. Richburg III, J. W. Wilcut, and G. R. Wehtje, "Toxicity of foliar and/or soils applied AC 263,222 to purple (Cyperus rotundus) and yellow nutsedge (C. esculentus)," Weed Science, vol. 42, pp. 398-402, 1993.

[29] J. W. Wilcut, E. F. Eastin, J. S. Richburg III, W. K. Vencill, F. R. Wells, and G. Wiley, "Imidazolinone systems for southern weed management in resistant corn," Abstracts of the Weed Science Society of America, vol. 33, p. 5, 1993.

[30] T. L. Grey, D. C. Bridges, and E. F. Eastin, "Residual weed control for peanut (Arachis hypogaea) with imazapic, diclosulam, flumioxazin, and sulfentrazone in Alabama, Georgia, and Florida: a multi-state and year summary," Proceedings American Peanut Research and Education Society, vol. 33, p. 19, 2001.

[31] J. S. Richburg III, J. W. Wilcut, D. L. Colvin, and G. R. Wiley, "Weed management in southeastern peanut (Arachis hypogaea) with AC 263,222," Weed Technology, vol. 10, no. 1, pp. 145-152, 1996.

[32] W. C. Johnson III, J. R. Chamberlin, T. B. Brenneman, J. W. Todd, B. G. Mullinix Jr., and J. Cardina, "Effects of paraquat and alachlor on peanut (Arachis hypogaea) growth, maturity, and yield," Weed Technology, vol. 7, no. 4, pp. 855-859, 1993.

[33] S. A. Senseman, Herbicide Handbook, Weed Science Society of America, Lawrence, Kan, USA, 9th edition, 2007.

[34] G. Wehtje, J. W. Wilcut, and J. A. McGuire, "Influence of bentazon on the phytotoxicity of paraquat to peanuts and associated weeds," Weed Science, vol. 40, pp. 90-95, 1992.

[35] T. L. Grey, D. C. Bridges, and E. P. Prostko, "Residual weed control with imazapic, diclosulam, and flumioxazin in southeastern peanut (Arachis hypogaea)," Peanut Science, vol. 30, pp. 22-27, 2003.

[36] Anonymous, Cobra ${ }^{\circledR}$ Specimen Label, Valent USA Corporation, Walnut Creek, Calif, USA, 2005.

[37] J. R. Harris, B. J. Gossett, T. R. Murphy, and J. E. Toler, "Response of broadleaf weeds and soybeans to the diphenyl ether herbicides," Journal Production Agriculture, vol. 4, pp. 407-411, 1991.

[38] W. J. Grichar, B. A. Besler, P. A. Dotray, W. C. Johnson III, and E. P. Prostko, "Interaction of flumioxazin with dimethenamid or metolachlor in peanut (Arachis hypogaea L.)," Peanut Science, vol. 31, pp. 12-16, 2004.

[39] J. W. Wilcut, "Summary of flumioxazin performance in southeastern peanuts," Proceedings Southern Weed Science Society, vol. 50, p. 7, 1997.

[40] W. J. Grichar, "Control of palmer amaranth (Amaranthus palmeri) in peanut (Arachis hypogaea) with postemergence herbicides," Weed Technology, vol. 11, no. 4, pp. 739-743, 1997.

[41] M. L. Ketchersid, T. E. Boswell, and M. G. Merkle, "Effects of 2,4-DB on yield and pod development in peanuts," Peanut Science, vol. 5, pp. 35-39, 1978.

[42] E. P. Prostko and T. A. Baughman, Eds., Peanut Herbicide Injury Symptomology Guide, Texas A\&M University, College Station, Tex, USA, 1999, SCS-1999-05.

[43] C. E. Simpson, M. R. Baring, A. M. Schubert, M. C. Black, H. A. Melouk, and Y. Lopez, "Registration of "Tamrun OL 02" peanut," Crop Science, vol. 46, pp. 1813-1814, 2006.

[44] R. R. Frans, R. Talbert, D. Marx, and H. Crowley, "Experimental design and techniques for measuring and analyzing plant responses to weed control practices," in Research Methods in Weed Science, N. D. Camper, Ed., pp. 29-46, Southern Weed Science Society, Champaign, Ill, USA, 3rd edition, 1986. 
[45] United States Department of Agriculture, Milled Peanuts: Inspection Instructions, United States Department of Agriculture, Agriculture Marketing Service, Fruit and Vegetable Division, Washington, DC, USA, 1993.

[46] W. J. Grichar, P. A. Dotray, B. A. Besler, and V. B. Langston, "Weed control programs in peanut (Arachis hypogaea) with diclosulam and ethalfluralin combinations," Texas Journal Agriculture and Natural Resources, vol. 19, pp. 62-71, 2006.

[47] W. J. Grichar and P. R. Nester, "Nutsedge (Cyperus spp.) control in peanut (Arachis hypogaea) with AC 263,222 and imazethapyr," Weed Technology, vol. 11, no. 4, pp. 714-719, 1997.

[48] C. M. Mayo, M. J. Horak, D. E. Peterson, and J. E. Boyer, "Differential control of four Amaranthus species by six postemergence herbicides in soybean (Glycine max)," Weed Technology, vol. 9, no. 1, pp. 141-147, 1995.

[49] S. D. Askew, J. W. Wilcut, and J. R. Cranmer, "Weed management in peanut (Arachis hypogaea) with flumioxazin preemergence," Weed Technology, vol. 13, no. 3, pp. 594-598, 1999.

[50] G. H. Scott, S. D. Askew, and J. W. Wilcut, "Economic evaluation of diclosulam and flumioxazin systems in peanut (Arachis hypogaea)," Weed Technology, vol. 15, pp. 360-364, 2001.

[51] W. J. Grichar and D. C. Sestak, "Effect of adjuvants on control of nutsedge (Cyperus esculentus and C. rotundus) by imazapic and imazethapyr," Crop Protection, vol. 19, no. 7, pp. 461-465, 2000.

[52] G. Wehtje, J. W. Wilcut, J. A. McGuire, and T. V. Hicks, "Foliar penetration and phytotoxicity of paraquat as influenced by peanut cultivar," Peanut Science, vol. 18, pp. 67-71, 1991.

[53] W. J. Grichar, R. G. Lemon, K. D. Brewer, and B. W. Minton, "S-metolachlor compared with metolachlor on yellow nutsedge (Cyperus esculentus) and peanut (Arachis hypogaea)," Weed Technology, vol. 15, no. 1, pp. 107-111, 2001.

[54] D. S. Carley, D. L. Jordan, R. L. Brandenburg, and L. C. Dharmasri, "Factors influencing response of Virginia market type peanut (Arachis hypogaea) to paraquat under weed-free conditions," Peanut Science, vol. 36, pp. 180-189, 2009.

[55] W. J. Grichar, A. E. Colburn, and P. A. Baumann, "Yellow nutsedge (Cyperus esculentus) control in peanut (Arachis hypogaea) as influenced by method of metolachlor application," Weed Technology, vol. 10, no. 2, pp. 278-281, 1996.

[56] M. G. Patterson, G. A. Buchanan, J. E. Street, and R. H. Crowley, "Yellow nutsedge (Cyperus esculentus) competition with cotton (Gossypium hirsutum)," Weed Science, vol. 28, pp. 327329, 1980.

[57] W. C. Johnson III and B. G. Mullinix, "Population dynamics of yellow nutsedge (Cyperus esculentus) in cropping systems in the southeastern coastal plain," Weed Science, vol. 45, no. 1, pp. 166-171, 1997.

[58] S. M. Brown, Weed Facts: Yellow and Purple Nutsedge, Cooperative Extension Service Bulletin 1043, Tifton, Ga, USA, 1990.

[59] D. A. Knauft, D. L. Colvin, and D. W. Gorbet, "Effect of paraquat on yield and market grade of peanut (Arachis hypogaea) genotypes," Weed Technology, vol. 4, pp. 866-870, 1990.

[60] A. S. Culpepper, T. L. Grey, W. K. Vencill et al., "Glyphosateresistant Palmer amaranth (Amaranthus palmeri) confirmed in Georgia," Weed Science, vol. 54, no. 4, pp. 620-626, 2006.

[61] D. E. Peterson, "The impact of herbicide-resistant weeds on Kansas agriculture," Weed Technology, vol. 13, no. 3, pp. 632635, 1999.

[62] M. J. VanGessel, "Glyphosate-resistant horseweed from Delaware,” Weed Science, vol. 49, no. 6, pp. 703-705, 2001.
[63] S. T. Lovell, L. M. Wax, M. J. Horak, and D. E. Peterson, "Imidazolinone and sulfonylurea resistance in a biotype of common waterhemp (Amaranthus rudis)," Weed Science, vol. 44, no. 4, pp. 789-794, 1996.

[64] D. L. Shaner, D. A. Feist, and E. J. Retzinger, "SAMOA(TM): one company's approach to herbicide-resistant weed management," Pesticide Science, vol. 51, no. 3, pp. 367-370, 1997. 


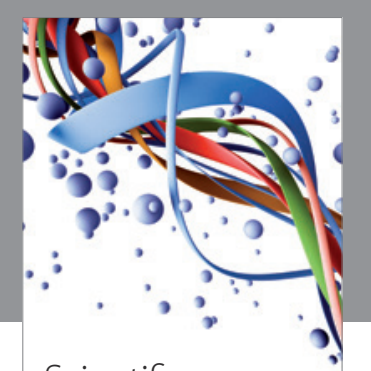

Scientifica
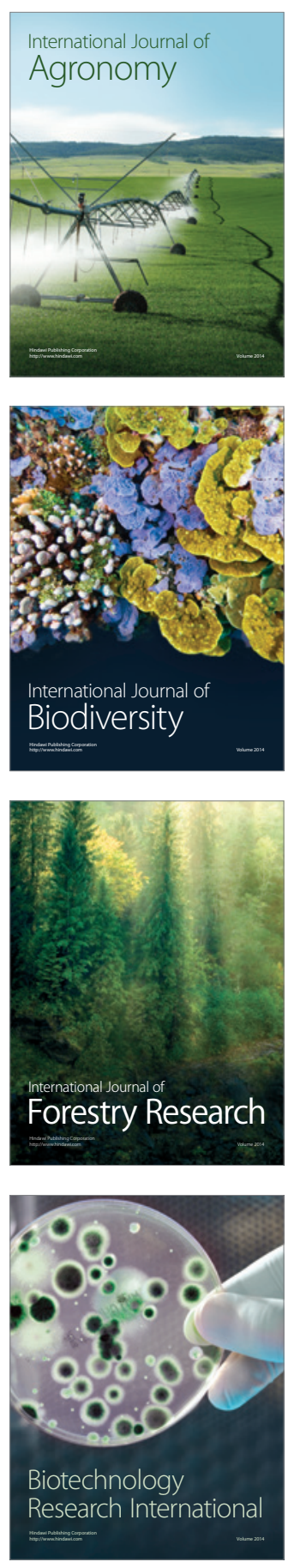
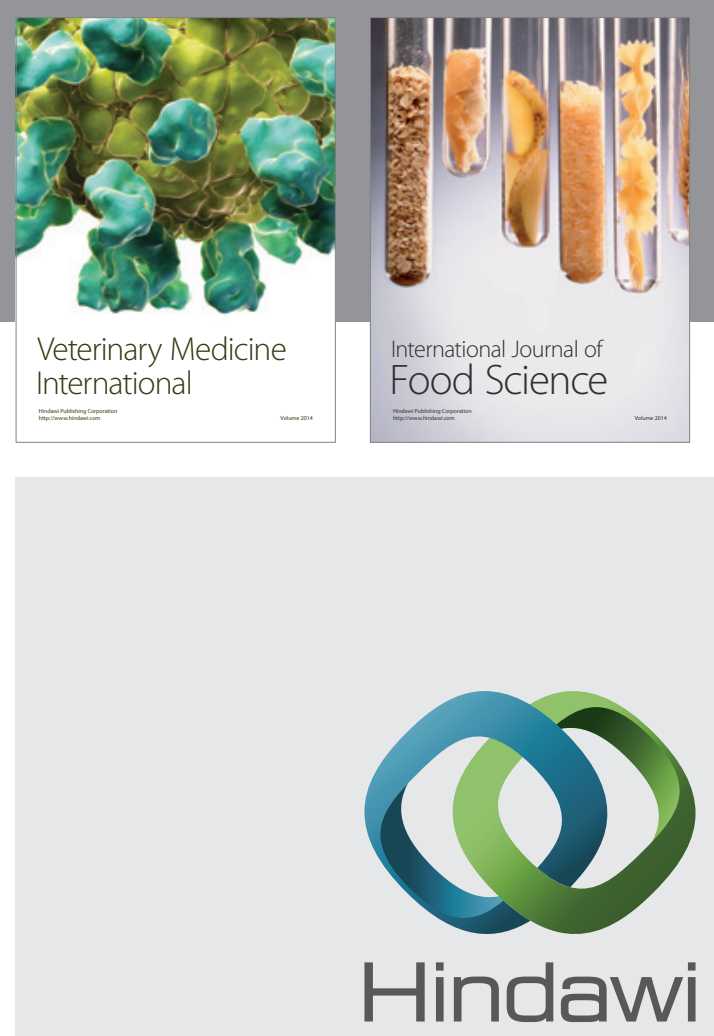

Submit your manuscripts at

http://www.hindawi.com
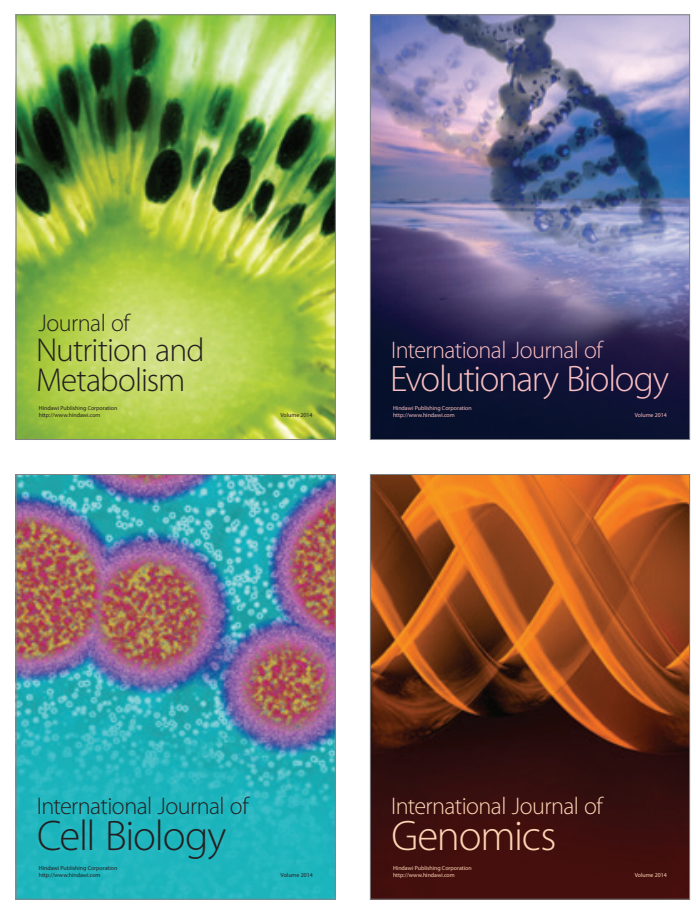
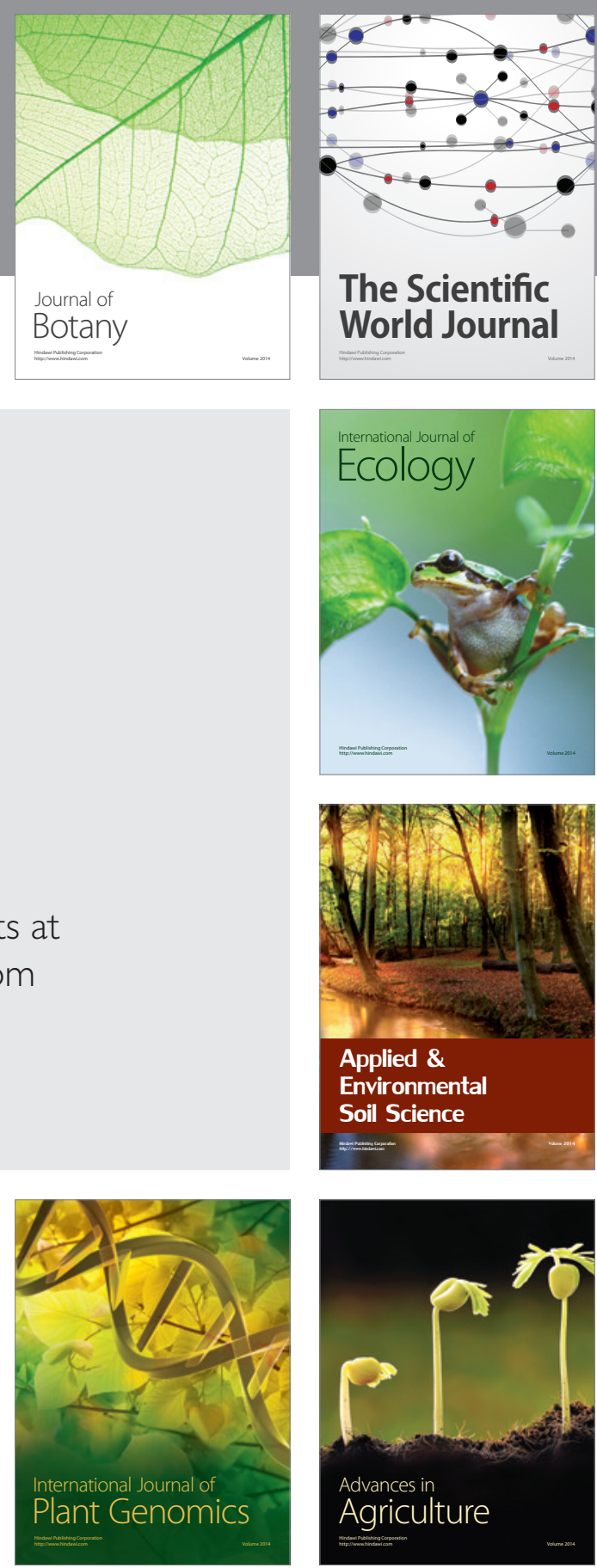

The Scientific World Journal
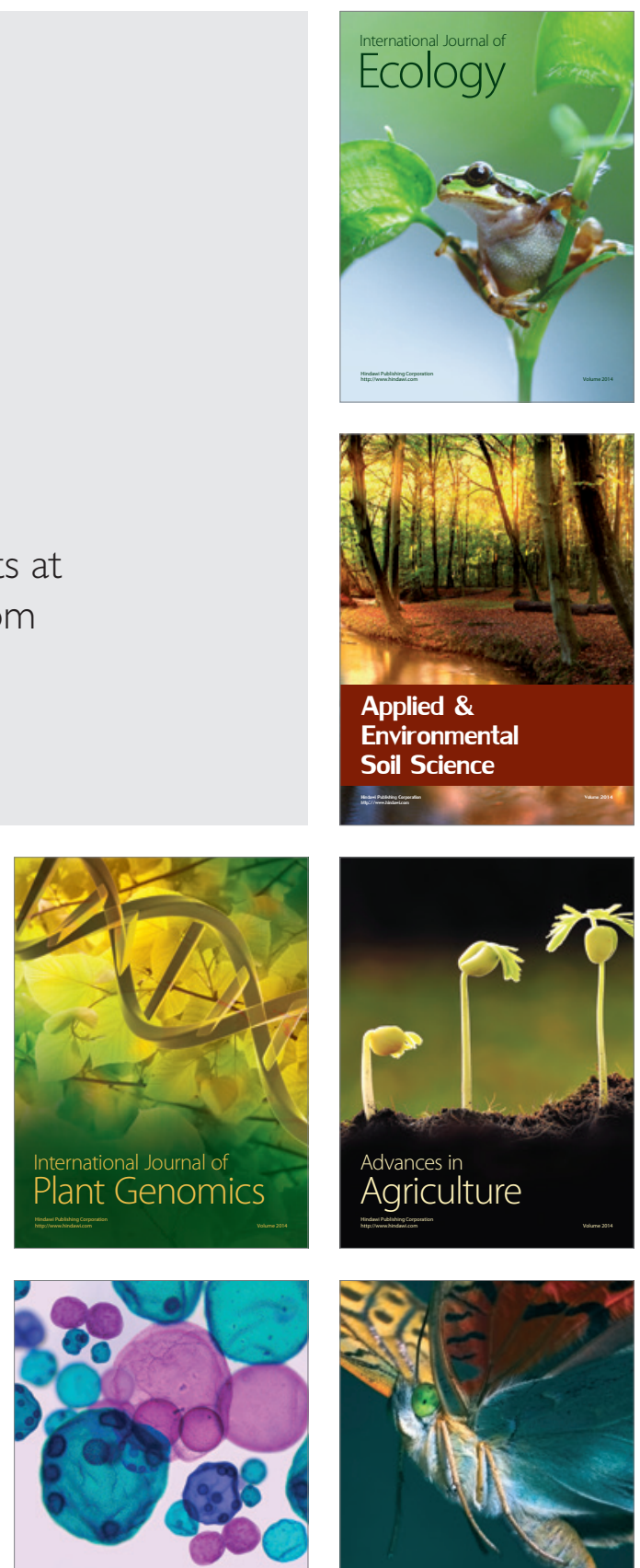

International Journal of Microbiology

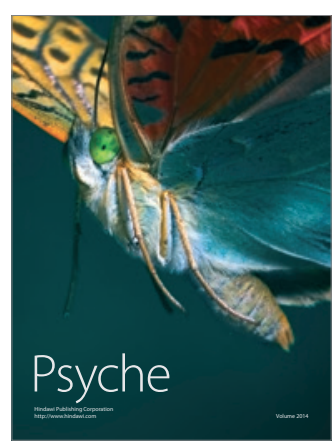

